\title{
POSSIBILITIES OF EMOTIONAL DISORDERS REDUCTION BY PROJECT- BASED LEARNING IN ICT CLASSES
}

\author{
Vladimíra LOVASOVÁ - Denis MAINZ
}

\begin{abstract}
Paper describes research conducted at Faculty of Education, University of West Bohemia in 2011 and 2012. Research is focused on monitoring an influence of project-based learning on psychological condition of high school students. It focuses mainly on emotional disorders included in qualitative dimensions of fear and sadness.
\end{abstract}

Key words: project-based learning, ICT, experience components, depressive and anxiety disorders.

\section{MOŽNOSTI REDUKCE PORUCH EMOCIONALITY V HODINÁCH INFORMATIKY PROSTŘEDNICTVÍM PROJEKTOVÉHO VYUČOVÁNÍ}

Resumé: Článek popisuje výzkum, který byl realizovaný na FPE ZČU v Plzni v letech 2011 až 2012. Je zaměřen na sledování vlivu projektového vyučování v informatice na psychický stav žáků střední školy. Zaměřuje se zejména na poruchy emocionality v kvalitativních dimenzích smutek a strach.

Klíčová slova: projektové vyučování, informatika, komponenty prožívání, depresivní a úzkostné stavy.

\section{1 Úvod}

Budování informační společnosti je v současné době jedním $\mathrm{z}$ nejdůležitějších procesů, probíhajících ve všech ekonomicky vyspělých zemích a vzdělávání $\mathrm{v}$ informačních a komunikačních technologiích je tedy nutnou podmínkou ovlivňující úspěch jednotlivce a celého společenství. Volba vyučovacích metod $\mathrm{v}$ informatice by tudíž měla co nejvíce korespondovat $\mathrm{s}$ aktuálními potřebami praxe. Jako vhodný ekvivalent tohoto požadavku se ve školním prostředí jeví projektová výuka. Potenciál projektového vyučování $\mathrm{v}$ oblasti přibližování reálnému životu byl již mnohými autory diskutován napřs. v metodikách Buckova institutu pro vzdělávání [1] a [2]. Problematiku implementace projektového vyučování do oblasti rozvoje znalostí a dovedností v informačních a komunikačních technologiích shledáváme z výzkumného hlediska poměrně opomíjenou. Stávající výzkumy převážně analyzují možnosti IKT jako podpưrného prostředku projektového vyučování [3], [4], [5]. Méně studií se již orientuje přímo na výhody a úskalí používání projektové výuky $\mathrm{v}$ informatice jako vyučovacího předmětu např. [6], [7]. Pouze ojediněle nacházíme výzkumy, které by propojovaly oba přistupy [8]. Vlivem projektového vyučování na psychický stav žáků se v českých podmínkách zabývala především Kratochvílová [9], která se však zaměřovala pouze na žáky prvního stupně základních škol.

Psychický stav žáků byl výzkumně sledován především za účelem podpory žákủ s emocionálními a behaviorálními problémy či v souvislosti $\mathrm{s}$ výskytem sociálně patologických jevů ve školách. Výzkumy jsou orientovány do oblastí vyučovacích a sociálních strategií, které má učitel volit, aby všichni žáci mohli plně využít svůj učební potenciál [10] [11] [12]. Řeší, zda učitelé mají dostatečnou podporu ve formě vzdělávací a institucionální intervence [13] a sledují vliv osobnostních charakteristik učitele na psychiku žáků apod. [14]. Většinová péče je věnována žákům základních škol. Studií, které by se primárně zabývaly psychickým stavem středoškolské mládeže je méně. Bývají cíleně zaměřovány na možnosti rozvoje sociálních, emocionálních a behaviorálních dovedností u středoškolské mládeže [15] [16] nebo se s nimi, tak jako $\mathrm{v}$ našem prípadě, setkáváme v souvislosti $\mathrm{s}$ emocionálním a sociálním zdravím. Našemu pojetí se z obsáhlejších studií přibližuje kvalitativní výzkum [17], který mapuje faktory emoční pohody u středoškoláků v kategoriích sebevědomí, autonomie, jistoty, frustrace, smutku, strachových emocí, dráždivosti apod., a to ve vztahu k celkové motivaci k učení. Jako jeden $\mathrm{z}$ důležitých aspektů se ukázaly vyučovací postupy učitele. Předkládaný článek popisuje výzkum, který se pokouší zaplnit výše nastíněná bílá místa tím, že problematiku uchopuje psychometrickým způsobem a zaměřuje se prímo na vliv projektového vyučování na emocionalitu žáků střední školy. 


\section{Teoretická východiska \\ 2.1 Deprese}

KKN 10 řadí depresivní stavy mezi poruchy nálad, které mohou mít endogenní nebo neurotický podklad [18]. Orientace na psychosomatické vymezení dává depresi do souvislosti $\mathrm{s}$ pocity patologické sklíčenosti a smutku vedoucích ke snížení energie a aktivity [19]. Příčiny vzniku depresí někteří autoři shledávají především v kauzalitě abnormity na neurofyziologické a neurobiochemické úrovni. Jiní preferují úlohu psychologických a filozofických komponent.

Jako teoretický podklad naší studie slouží především kognitivní model etiopatogeneze deprese A. T. Becka, který vychází z určující úlohy myšlení ve vztahu $\mathrm{k}$ depresím. Na základě zkušeností se vytváŕí relativně trvalé schéma kognitivní organizace individua. Latenci této organizace uvolňují další negativní zkušenosti a zátěžové situace, které následně opět posilují kognitivní schémata orientovaná na ztráty a negativní očekávání. Připojené afekty pak samy působí jako stimuly. Beckova „kognitivní triáda“ obsahuje negativní sebehodnocení, projektivní percepci zkušeností a negativní anticipaci budoucího. Jako klíčový prvek se proto jeví hodnocení nové zkušenosti, kterou adolescent s projektivním vyučováním získá.

\section{2 Úzkost}

Úzkost lze považovat za souhrnné označení komplexu subjektivních prožitků nejistoty, obav, neklidu, stísněnosti a nepř́ijemného vnitřního napětí [19]. Narušuje adaptabilitu a je doprovázena vegetativními a neuropsychickými obtížemi. Specifickou charakteristikou úzkosti je anonymita. Také $\mathrm{v}$ př́padě etiopatogeneze úzkosti se setkáváme s mnohotvárností prístupů. Psychofyziologické hledisko považuje úzkost za emoci a tím i za součást neurofyziologických a neurobiologických procesů. Goodyer [20] $\mathrm{v}$ tomto smyslu poukazuje na dva typy teorií emocí. Emoce jsou aktivátory kognice a jednání, zároveň však mají regulační efekt fyziologických, kognitivních a behaviorálních struktur v souvislosti se zkušenostmi.

Jako protipól uvedených př́stupů se jeví hlediska filozoficko-psychologická, která prožívání individua vztahují ke komponentám hodnotově obsahovým. Jako prŕíklad lze uvést Kierkegaardovu negativní dialektiku [21], který na základě rozlišování úzkosti ze světa a úzkosti před sebou objasňuje protismyslnou strukturu bytí. Jaspers za základní formy úzkosti považuje tzv. úzkost holého bytí a existenciální úzkost. $\mathrm{S}$ tímto filozoficko-existenciálním pojetím se v našich podmínkách setkáváme např̀. u Langmaiera [22], který úzkost vymezuje přímo jako afekt, jehož funkcí je signalizace existenciálního ohrožení. Podle Vašiny [23] se úzkost $\mathrm{v}$ dnešní době rozvíjí především $\mathrm{v}$ případě neuspokojení pocitů jistoty a bezpečí v sociální skupině.

\section{Cíl a design výzkumu}

Výzkumné šetření je zaměřeno na vliv projektového vyučování $\mathrm{v}$ informatice na psychický stav žáků střední školy. Cílem výzkumu bylo zjistit, zda u žáků střední školy dojde po zařazení projektové výuky $\mathrm{v}$ informatice $\mathrm{k}$ redukci subjektivně vnímané intenzity depresivních a úzkostných stavů.

Uvedená formulace výzkumného cíle vychází již ze samotné charakteristiky psychického stavu, který je $z$ širšího hlediska chápán jako „dynamická veličina, pro níž je př́iznačná proměnlivost aktivace psychiky spolu se změnami kvalit emocionálního vyladění“ [24]. Dynamický charakter odráží to, že změna psychického stavu je průvodním jevem jakékoli situační změny, a to $\mathrm{v}$ obou základních znacích (aktivace psychiky a prožívání). Za situační změnu u žáků považujeme zařazení nového způsobu výuky. Změny psychického stavu lze však posuzovat pouze v kontextu konkrétní subjekt a konkrétní situace, nebot' jsou výrazně vázané na osobnostní strukturu jejich nositele. $\mathrm{Za}$ účelem naplnění výzkumného cíle byl navržen následující design výzkumu:

Př́ipravná fáze obsahovala volbu cílové skupiny žáků, př́ípravu projektové výuky a návrh organizace výzkumu.

V Realizační fázi výzkumu jsme jako metodu sběru dat použili z hlediska validity a reliability standardizovaný psychometrický nástroj SUPSO. Data byla vyhodnocována standardizovaným postupem dle manuálu SUPSO. Matematické zpracování výsledků bylo řešeno pomocí váženého průměru a relativní četnosti. Ke statistickému zpracování výsledků byl použit T-test a F-test. Výsledky jsme formulovali $\mathrm{v}$ podobě relačních závěrů.

\section{Vzorek respondentů}

$Z$ důvodu snadnější realizace výzkumu jsme jako cílovou skupinu zvolili žáky 2. ročníku dvou českých středních škol, na kterých je informatika považována za jeden $\mathrm{z}$ profilových předmětů. 
Jednalo se o Střední průmyslovou školu elektrotechnickou a Střední školu informatiky a finančních služeb. Žáci 2. ročníků jsou již na takové úrovni, že mohou samostatně provádět střednědobé projekty a vyučovací obsah bylo možné standardizovat. Do šetření byly zahrnuty 4 tř́́dy. Na každé z uvedených škol to byla vždy jedna trída experimentální, tzn. s aplikací projektové metody a jedna třída srovnávací. Výzkumný soubor tvořilo celkem 47 žáků v experimentální skupině a 40 žáků ve srovnávací skupině. Zkoumaný vzorek tvořili z $90 \%$ chlapci. Věk posuzovaných se pohyboval $\mathrm{v}$ rozmezí 17-19 let.

\section{Organizace výzkumu}

Před započetím experimentu byly u všech žáků zjišt'ovány kvality psychického stavu prostřednictvím psychodiagnostické metody. U dvou tř́́d (z každé školy jedné) následovala výuka prostřednictvím připravených projekti̊, ve zbylých dvou třídách probíhala výuka stejného obsahu beze změny způsobu výuky. Po ukončení projektové výuky byli žáci všech čtyř tříd opět měřeni, a to shodným nástrojem jako $\mathrm{v}$ předchozím př́ípadě.

\section{Charakteristika aplikovaných projektů}

Ve snaze dodržet zásady projektového vyučování a eliminovat prvky jiných alternativních metod, jako jsou problémové vyučování nebo integrovaná tematická výuka, byly projekty navrženy dle učitelských př́ruček Buckova institutu pro vzdělávání [1] [2]. Obsahová část řešených projektů byla navržena tak, aby korespondovala $\mathrm{s}$ učivem tematické oblasti probírané ve srovnávacích trrídách. Tématem učebního bloku bylo editování a tvorba rastrové a vektorové grafiky. Výstupem projektů měl být navržený a vyřešený grafický design webové presentace reálně existující firmy s implementací fotogalerie presentující firemní produkty a výrobní postupy. Použité techniky a postupy výsledného zpracování grafického návrhu byly presentovány metodou akvária (fishbowl) a obhajovány před zbytkem trrídy, učitelem a spoluvlastníkem firmy.

\section{Dotazník SUPSO}

Dotazník SUPSO [24] (Postihování a hodnocení struktury a dynamiky subjektivních prožitků a stavů) umožňuje sledování vztahů mezi dynamikou psychického stavu a situačními i interakčními proměnnými. Zaměřuje se na sedm komponent psychického stavu.
Psychická pohoda $(P)$ vypovídá o tom, zda se jedinec cítí dostatečně svěží, spokojený, psychicky vyrovnaný, optimistický a dobře naladěný.

Aktivnost, činorodost (A) představuje pocity síly a energie spojené $\mathrm{s}$ pohotovostí $\mathrm{k}$ aktivní interakci a reakci na situační změny. Je definovaná především činorodostí a průbojností.

Impusivnost, odreagovávání se (O) znamená racionální sebekontrolou neřízené uvolňování psychického napětí. Obsahuje náladovost, výbušnost, podrážděnost a obtížné sebeovládání.

Psychický nepokoj, rozlada (N) se projevuje psychickým a motorickým neklidem, nespokojeností, netrpělivostí a roztěkaností.

Psychická deprese, pocity vyčerpání (D) obsahuje tendenci k pasivitě a apatii, pesimismus, otrávenost, pocity slabosti apod.

Úzkostné očekávání, obavy (U) zahrnuje komplex pocitů nejistoty, psychického napětí, úzkostné nálady, obav z budoucnosti apod.

Skličenost (S) charakterizuje pasivní proživání negativních důsledků psychické zátěže, kterou reprezentují pocity smutku, precitlivělosti, osamělosti, neštěstí apod.

Uvedené komponenty lze dle emoční polarity členit na komfortní a dyskomfortní. Do kategorie komfortních řadíme komponenty $\mathrm{P}$ a $\mathrm{A}$, nebot' jsou subjektivně vnímané jako př́jemné a jejich kvalita roste sycením jednotlivých škálových položek. Dimenzi dyskomfortu naplňují komponenty zbylé. Subjektivně vyjadřují nepř́ijemné prožitkové i interakční vyladění a oproti předcházející dimenzi jejich kvalita roste nesycením. Dle směřování jednotlivých komponent psychického stavu rozlišujeme dimenze prožívání versus aktivace. Komponenty $\mathrm{P}, \mathrm{S}$ a $\mathrm{U}$ vyjadřují různé kvality prožívání a komponenty A, O, N stránky reagování. Kategorii D (psychická deprese, pocity vyčerpání) považujeme za hraniční a přechodovou, nebot' depresivní stavy vždy obsahují složky emocionální i dynamogenickou. Symptomatologie depresivních a úzkostných stavů popsaná $\mathrm{v}$ rámci teoretických východisek však umožňuje ještě další klasifikaci faktorů SUPSO, a to i nad rámec manuálu nástroje. Depresivní stav vedle komponenty D (psychická deprese, pocity vyčerpání) sytí ještě komponenta $\mathrm{S}$ (sklíčenost) a komponenta A (aktivnost činorodost). Úzkostnému stavu symptomaticky odpovídají komponenty U (úzkostné očekávání, obavy), N (psychický nepokoj, rozlada) a O (impulsívnost, odreagovávání se). 


\section{Výsledky šetření}

Následující graf poskytuje detailní pohled na změny jednotlivých sledovaných komponent prožívání v experimentální i srovnávací skupině. Jedná se již o rozdíly vážených průměrů mezi prvním a druhým měřením.

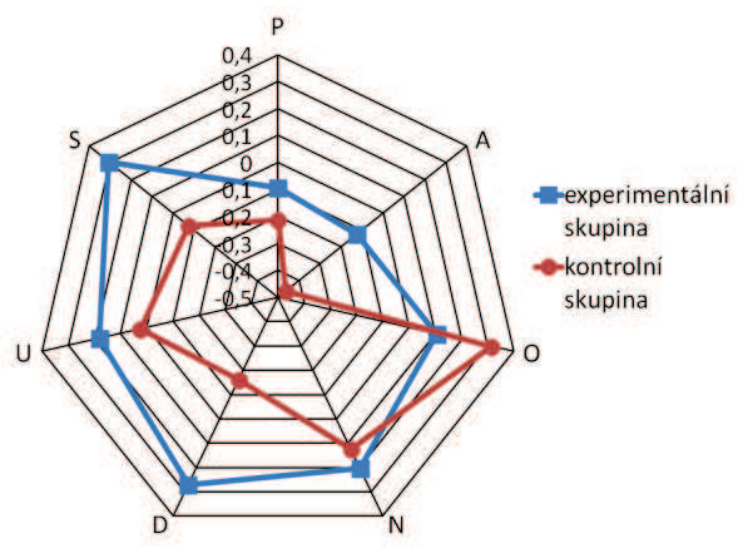

Obr 1: Detaily změn v průběhu experimentu

\subsection{Depresivní stav}

V experimentální skupině došlo $\mathrm{v}$ průběhu projektové výuky $\mathrm{k}$ minimalizaci depresivních pocitů (D). U srovnávací skupiny naopak celkový vážený průměr tohoto negativního stavu vzrostl. Při pohledu na podíly žáků $\mathrm{v}$ kvalitativních kategoriích zjištujeme, že rozdíl mezi žáky srovnávací a experimentální skupiny, u kterých došlo v oblasti depresivních stavů ke zlepšení je 44\%. Na druhém okraji spektra, tzn. zhoršené prožívání, bylo $\mathrm{v}$ experimentální skupině vykázáno u 19\% žáků oproti $55 \%$ žáků ve srovnávací skupině. P-hodnota se pohybuje na hranici statistické významnosti, $\mathrm{p}=0,036$.

U obou skupin registrujeme pokles celkového váženého průměru aktivity a činorodosti $(\mathrm{A})$. Ve srovnávací skupině se však jedná o výrazný záporný posun. Této tendenci odpovídá i distribuce kategorií odpovědí. Podíl žáků experimentální skupiny ku žákům srovnávací skupiny v kategorii „zhoršení proživání“ činil 47\% : 76\%. U experimentální skupiny byly prokázány statisticky velice významné rozdíly mezi prvním a druhým měřením $(p=0,0005)$.

Zařazením projektové výuky došlo také $\mathrm{k}$ průměrné redukci pocitů sklíčenosti a rezignace (S). U srovnávací skupiny registrujeme mírné zvýšení. U 55\% žáků, u kterých probíhala projektová výuka, zaznamenáváme zlepšení prožívání v této oblasti. U srovnávací skupiny to bylo $30 \%$. Zhoršené prožívání vycházelo u $30 \%$ žáků srovnávací skupiny a pouze u $15 \%$ skupiny experimentální. Mimo faktor $\mathrm{S}$ byl u všech ostatních faktorů zjištěn statisticky významný rozdíl $\mathrm{v}$ rozptylech, přičemž ve druhém měření byl vždy rozptyl vyšší.

\section{2 Úzkostný stav}

Celkový vážený průměr impulsivnosti $(\mathrm{O})$ a spontánní potřeby odreagování se u obou skupin snížil, u experimentální skupiny však méně než u srovnávací. Tomuto odpovídají i podíly žáků $\mathrm{v}$ jednotlivých kvalitativně obsahových kategoriích, kde experimentální skupina dopadla hưre. Oproti srovnávací skupině vykazuje menší podíl žáků, u kterých se prožívání zlepšilo $(55 \%$ : 47\%) a nárůst podílu žáků se zhoršením prožíváním (20\%: 28\%). P hodnota $\mathrm{u}$ faktoru $\mathrm{O}=0,0007$.

Oblast psychického nepokoje a rozladění $(\mathrm{N})$ vykazuje u obou skupin mírný úbytek celkového váženého průměru, u experimentální skupiny větší. Rozložení podílů žáků $\mathrm{v}$ kvalitativních kategoriích nenaznačují tendenční rozdíly mezi skupinami, nebot' jsou kompenzovány distribucí $(\mathrm{p}=0,0007)$.

Dle celkového váženého průměru se nepř́ijemně prožívané úzkost a obavy (U) v průběhu výuky zmírnily u obou skupin, výrazněji u experimentální. Procentuální rozložení uvnitř skupin však vypovídá spíše ve prospěch kontrolní (srovnávací) skupiny. Jako pozitivní se u experimentální skupiny jeví přesun ze zhoršeného prožívání do kategorie stagnace.

Uvedený výčet naznačuje pozitivní potenciál projektové výuky ve všech sledovaných komponentách vyjma impulsivnosti a spontánního odreagování se. Shrneme-li výše uvedené výsledky dle klíčových dimenzí komfortu a dyskomfortu, zjišt'ujeme, že komfortní komponenty se ani při druhém měření nepohybovaly $\mathrm{v}$ pozitivních polaritách. Dyskomfortní komponenty byly při druhém měření u experimentální skupiny pozitivní všechny. Jinými slovy, zařazením projektové výuky se nepodařilo posílit pozitivní emocionalitu, ale ve všech př́padech došlo $\mathrm{k}$ redukci negativních pocitů, které mohou vyučovací proces provázet. Zároveň v experimentální skupině došlo $\mathrm{k}$ jednoznačnému posunu od pasivity a pasivního negativního prožívání směrem k aktivní interakci.

Za nejvýraznější ukazatele lze považovat snížení intenzity depresivních pocitů a pocitů sklíčenosti a zároveň výrazně menší úbytek aktivnosti a činorodosti, což $\mathrm{v}$ našem pojetí odpovídá symptomatice depresivního stavu. Pro bližší prredstavu přikládáme grafy zobrazující 
obsahově kvalitativní kategorizaci u faktorů $\mathrm{D}$ a S.

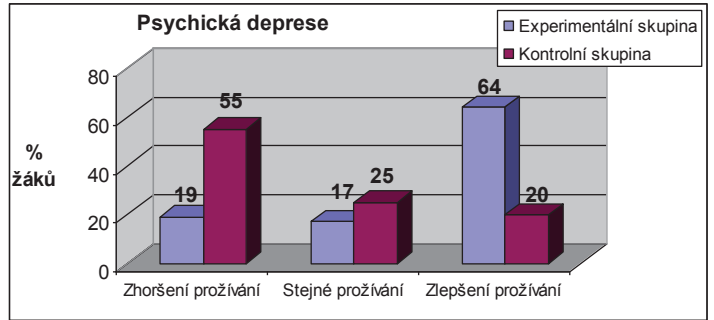

Obr 2: Obsahově kvalitativní kategorizace u faktoru $D$

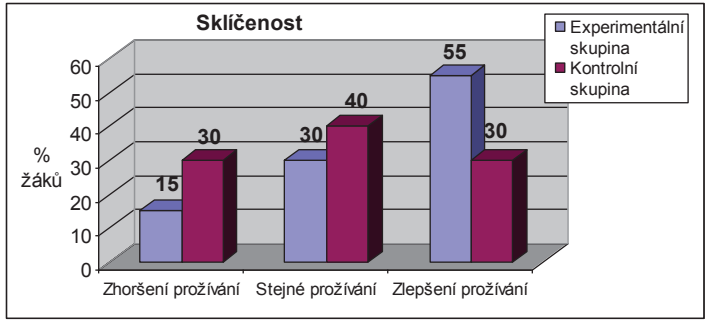

Obr 3: Obsahově kvalitativní kategorizace u faktoru $S$

$\mathrm{V}$ př́ípadě redukce úzkostného stavu nelze výsledky šetření považovat za průkazné. Pozitivní posun byl shledán pouze u faktoru $\mathrm{U}$ (tzn. jednoho ze tř́i sledovaných) a ani v tomto př́ípadě se nejedná o rovnoměrnou distribuci mezi žáky, ale o výraznou změnu intenzity prožívání jednotlivců.

\section{Závěr}

Projektové vyučování se může jevit jako vysoce univerzální $\mathrm{v}$ souvislosti $\mathrm{s}$ jednotlivými styly učení [25], nemusí však vyhovovat všem žákům.

V př́ípadě ovlivňování depresivních stavů žáků má dle našeho šetření projektové vyučování výrazný potenciál, nebot' strategie PBL umožňují pozitivně působit na celou Beckovu kognitivní triádu. Skupinová odpovědnost za výsledek umožňuje minimalizovat individuální negativní sebehodnocení a rozmělňuje i výši požadavků a překážek. Negativní anticipaci budoucího jako něčeho nekonečně přetrvávajícího redukuje časové ohraničení projektu.

Přestože $\mathrm{v}$ rámci naší sondy nedošlo $\mathrm{u}$ žáků $\mathrm{k}$ redukci úzkostných stavů, domníváme se, že projektové vyučování může pozitivně působit i v této oblasti. Úzkost totiž úzce souvisí s celkovou adaptabilitou jedince. Z hlediska výzkumného cíle pak mohlo být negativním prvkem to, že žáci dosud neměli s projektovou výukou tohoto typu zkušenosti a svoji sociální roli v projektové skupině teprve odhadovali.
Z tohoto důvodu budeme vliv projektového vyučování na emocionalitu žáků dále výzkumně sledovat.

\section{Literatura}

[1] MARKHAM, Thom. Project based learning handbook: a guide to standards-focused project based learning for middle and high school teachers. 2nd ed. Novato, Calif: Buck Institute for Education, 2003. s. 4 - 6, s. $10-179$. ISBN 09-740-3430-4.

[2] MARKHAM, Tom, LARMER, John a ROSS, David. PBL starter kit: to-the-point advice, tools and tips for your first project. 1st ed. Novato, CA: Buck Institute for Education, 2009. s. 4 - 5, s. 28 - 135. ISBN 978-097-4034-324.

[3] ARDAIZ-VILLANUEVA, Oscar, Xabier NICUESA-CHACÓNA, Oscar BRENEARTAZCOZA, María Luisa SANZ DE ACEDO LIZARRAGAB a María Teresa SANZ DE ACEDO BAQUEDANOB. Evaluation of computer tools for idea generation and team formation in project-based learning. Computers and Education. 2011, roč. 56, č. 3, s. 700-711. ISSN 0360-1315.

[4] LING-CHIAN, Chang a Leeb GREG C. A team-teaching model for practicingprojectbasedlearning in highschool: Collaboration between computer and subject teachers. Computers and Education. 2010, roč. 55, č. 3, 961 - 969. ISSN 0360-1315.

[5] KÖSE, Utku. Awebbasedsystem for projectbasedlearningactivities in "webdesign and programming" course. Procedia, social and behavioral sciences. 2010 , roč. 2 , č. 2, $1174-$ 1184. ISSN 1877-0428.

[6] PUCHER, Robert a Martin LEHNER. ProjectBasedLearning in ComputerScience AReview of More than 500Projects. Procedia, social and behavioral sciences. 2011, roč. 29, č. 1, 1561-1566. ISSN 1877-0428.

[7] KAI WAH CHU, Samuel, S.K. TSE a Ken CHOW. Using collaborativeteaching and inquiryproject-basedlearning

helpprimaryschoolstudentsdevelopinformationlite racy and informationskills. Library \& Information Science Research. 2011, roč. 33, č. 2, 132-143. ISSN 0740-8188.

[8] OTAKE, Mihoko, Ryo FUKANO, Shinji SAKO, Masao SUGID, Kiyoshi KOTANI, Junya HAYASHI, Hiroshi NOGUCHI, Ryuichi YONEDA, Kenjiro TAURA, Nobuyuki OTSU a Tomomasa SATO.

Autonomouscollaborativeenvironment for project-basedlearning. Robotics and autonomous 
systems. 2009, roč. 57, č. 2, 134-138. ISSN 0921-8890

[9] KRATOCHVÍLOVÁ, Jana. Jak vnímají a prožívají projektové vyučování žáci a učitelé? In: Sociální a kulturni souvislosti výchovy a vzdèlávání: sborník anotací přispěvků účastniků 11. konference České asociace pedagogického výzkumu: 10.-12. zář́ 2003 Pedagogická fakulta Masarykovy univerzity v Brně. Brno: Paido, 2003, s. 1-6. ISBN 80-7315-046-8.

[10] EVANS, Jennifer, Angela HARDEN a James THOMAS. What are the effective strategies to support pupils with emotional and behavioral difficulties?. Journal of Research in Special Educational Needs. 2004, roč. 4, č. 1, s. 2-16. ISSN 1471-3802.

[11] ISZATT, J. a T. WASILEWSKA. Nurture groups: an early intervention model enabling vulnerable children with emotional and behavioural difficulties to integrate successfully into school. Education and Child Psychology. 1997, roč. 14, č. 3, s. 63-70.

[12] HUMPHREY, Neil et.al. Primary social and emotional aspects of learning (SEAL): evaluation of small group work. 1. vyd. London: Dept. for Children, Schools and Families, 2008. s. 75-89. ISBN 978-1-84775-295-6.

[13] MEIJER, J.W. Inclusive Education and Effective Classroom Practices. Østre: European Agency for Development in Special Needs Education, 2001. s. 42, 266 s. ISBN 87-9059115-1.

[14] FORLIN, Chris, John HATTIE a Graham DOUGLAS. Inclusion: Is it stressful for teachers?. Journal of Intellectual and Developmental Disability. 1996, roč. 21, č. 3, s. 199-217. ISSN 1366-8250. DOI: $10.1080 / 13668259600033141$.

[15] MOSLEY, Jenny a Marilyn TEW. Quality circle time in the secondary school: a handbook of good practice. London: D. Fulton Publishers, 1999, 150 s. ISBN 18-534-6616-6.

[16] PAULA, Smith et al. Secondary social, emotional and behavioural skills (SEBS) pilot evaluation. Nottingham: DfES Publications, 2007, 120 s. ISBN 978-184-7750-020.

[17] SIXSMITH, Judith, Carolyn KAGAN a Paul DUCKETT. Pupils' emotional well-being in school: Preliminary Report for the Healthy Schools' Team. 1st ed. Manchester: Research Institute for Health and Social Change Manchester Metropolitan University, 2004, s. 9$89,114 \mathrm{~s}$.

[18] NÁHUBEK, K., BOUCHAL, M. Psychiatrie a medicinská psychologie pro stomatologický směr. Brno: Univerzita J.E. Purkyně, 1979.

[19] KOTASOVÁ, Jarmila. Vybrané kapitoly z patopsychologie. Vyd. 1. Olomouc: Hanex, 2000, 245 s. ISBN 80-857-8330-4.

[20] GOODYER, M. I. Life experiences, Development and Childhood Psychopathology. New York : J.Wiley and Sons, 1990.

[21] SHULZ, W. Philosophie in der veränderten Welt. Pfullingen: Neske, 1972.

[22] LANGMEIER, J. Vývojové aspekty úzkosti. Československá pediatrie. 1977, roč. 32, č. 11, s. 646-647.

[23] L., Vašina. Sanoterapie v psychosomatické praxi. Brno: Masarykova Univerzita, 1995.

[24] Mikšík, O., 2004. Dotazník SUPSO, Psychodiagnostika s.r.o. Brno. s. 246-247.

[25] MAREŠ, Jiř́i. Styly učení žákủ a studentů. 1.vyd. Praha: Portál, 1998, 239 s. ISBN 80-7178246-7.

Mgr. Vladimíra Lovasová, Ph.D.

Katedra psychologie

Fakulta pedagogická Západočeské univerzity

v Plzni

Chodské náměstí 1

30614 Plzeň

Tel: +420377636377

E-mail: lovasova@kps.zcu.cz

Www pracoviště: www.kps.zcu.cz

Mgr. Denis Mainz

Katedra výpočetní a didaktické techniky

Fakulta pedagogická Západočeské univerzity

v Plzni

Klatovská tř. 51

30619 Plzeň, Č́R

Tel: +420 724286955

E-mail: dmainz@kvd.zcu.cz

Www pracoviště: www.kvd.zcu.cz 